\title{
Student's educational and occupational aspirations (study in Batak Karo and Melayu Deli cultural)
}

\author{
Suci Rahma Hanum ${ }^{1}$, Muri Yusuf ${ }^{2}$, Herman Nirwana ${ }^{3}$ \\ ${ }^{123}$ Universitas Negeri Padang, Padang - Indonesia, (soecen_han@yahoo.co.id)
}

\begin{abstract}
Every students have educational and occupational aspirations. The factors affecting the educational and occupational aspirations of students are cultural and gender. Aims of this research were to examine the differences educational and occupational aspirations between male and female of Batak Karo and Melayu Deli students. The population were 823 and samples 268 students. The instrument used the educational aspiration scale $(R=0,853)$ and occupational aspirations scale $(R=0,852)$. The data were analyzed by using MANOVA. The result of this research shows that there is not significant the difference on educational and occupational aspirations between Batak Karo and Melayu Deli students, there was significant difference on educational and occupational aspirations between Batak Karo male and female students, there was significant differences on educational aspirations between Melayu Deli male and female students and there was not significant difference on occupational aspirations.
\end{abstract}

Keywords: educational aspirations, occupational aspirations, gender, cultural

\section{Introduction}

Elections and preparing themselves to determine a further education or occupation is an important developmental task in adolescents. Teenagers who are at a high school level students who already have the aspiration to education and employment. In accordance with that proposed by Yusuf (2002: 59) that, "Before the teenager managed to enter the world of work, in fact, they have been put forward either directly or indirectly to the parents, brother/sister, peers, or teacher/tutor, about ideals education and work in the future". They've thought of every aspiration that will support the success to achieve the desired education and employment.

Quaglia \& Cobb (1996) defines aspirations as an individual's ability to identify and set goals for the future, so what the expectations in the present can be realized through the capabilities of the individual. Aspiration is a supporting factor to achieve a better life. When students have aspirations then they already know about the education that will support the desired positions. McClelland (2013: 26) argues that the definition of educational aspirations,"Education aspirations typically Refers to how far a student hopes to progress in school, and the degree of education they seek to Achieve". 
Rojewski (in Brown \& Lent, 2005:132) defines the occupational aspirations is "An individual's Expressed career related goals or choices"

Many factors affect individual aspiration towards education and the desired positions. Gutman \& Arkeman (2008) describes the factors that affect students' educational aspirations and positions, namely: family socioeconomic status, cultural background, gender, and age. The opinion indicates that the factors that affect students' educational aspirations and positions are gender and culture. Nirwana (2003) describes the values of the culture of a community with other communities is a factor that could explain the different aspirations of students.

This was confirmed by the results of research Mau (1995) which shows American students have educational aspirations and a higher position than the other race-based groups. In addition, Suslu study (2014) comparing the educational aspirations and positions Turkish and American students found that there was no significant difference between students turkey and American students. Both the above results indicate that inconsistency results of research on educational aspirations and positions students. The inconsistency of these findings is likely due to the influence of culture.

Based on the results of our analysis of data obtained from counseling teacher at SMAN 1 Galang (Melayu Deli cultral) that there are still many students who lack the aspiration to pursue higher education, visible from 190 students of class XII only 47\% of students who participated in SNMPTN 2017. More than 320 students of SMA Negeri 1 Sibolangit (Batak Karo cultural) class XII only $12.5 \%$ of students who take SNMPTN 2017. Students who do not follow SNMPTN 2017 of both schools reasoned that students want to work directly and in no mood to go to college, The results of data analysis showed that the tendency of differences in educational aspirations among student's Batak Karo and Melayu Deli cultural. The influence of cultural factors on students' educational aspirationsand positions allows for diversity of educational aspirations and positions students of different cultural backgrounds. It is caused by different values are adopted in a particular cultural community groups. The values of the culture Batak Karo different from the Melayu Deli community. Differences in cultural values prevailing in society Batak Karo and Melayu Deli give different roles to men and women which cause different behaviors they display.

Batak Karo still tends to assume a tad more socially valuable than girls. Batak Karo culture draw lineage (lineage) of the seed of the father (patrilineal). Batak Karo society has a clan system(clan). For boys, this clan will be inherited from generation to generation. So, in terms of education, men are more preferred than women (Prints, 2014). Unlike the case with civilized society Batak Karo, the Melayu Deli culture descent determine the composition and kinship ties. The offspring bonding is parental or bilateral, the mother and father have the same rights, as well as boys and girls. The right to education is equally so is not restricted between male and female education (Basyarsyah \& Syaifuddin, 2002).

The role of the men and women in Culture Batak Karo likely to cause differences between the educational aspirations and positions where the male and female students male students is higher aspirations than female students. While the Melayu Deli likely there is no difference because it is caused, not their different roles and responsibilities in the Melayu Deli to men and women. The general objective of this research is (1) Testing differences educational aspirations and positions students cultural backgrounds Batak Karo and Melayu Deli. Then specifically the purpose of this study is (2) Testing differences educational aspirations and positions between male and female students cultural backgrounds Batak Karo, and then (3) Testing differences educational aspirations and positions between male and female students cultural backgrounds Melayu Deli.

\section{Method}

This study uses a quantitative approach with descriptive comparative, The study population was 823 students, consisting of 414 students of SMA Negeri 1 Sibolangit (Batak Karo cultural) and 409 
students of SMA Negeri 1 Galang (Melayu Deli cultural). The research sample as many as 269 students (135 students Batak Karo cultural and 133 students Melayu Deli cultural) are selected by techniques Cluster Stratified Random Sampling. The instrument used in this study of scale educational aspirations (SEA with reliability 0.852) and scale occupational aspirations (SOA with reliability 0.853 ), to achieve the purpose of the investigation, as noted above, namely data analysis techniques used in multivariate analysis (MANOVA).

\section{Results and Discussion}

Differences Educational and Occupational Aspirations Students in Batak Karo and Melayu Deli Cultural

Results showed that there were no differences in educational aspirations and occupational aspirations between students Batak Karo and Melayu Deli cultural, with $F_{\text {hitung }}$ on educational aspirations is 1,962 and significance level of 0.162 . Occupational aspiration get results $F_{\text {hitung }}$ equal to 2.477 and a significance level of 0.117. In accordance with hypothesis testing criteria, if $\operatorname{Sig}>0.05$, meaning that there are no significant differences between educational and occupational aspirations students' Batak Karo and Melayu Deli Cultural.

\section{Differences Educational and Occupational Aspiration Students Men and Women Batak Karo Cultural}

Results showed that there were differences in educational aspirations and occupational aspirations between men and women students' Batak Karo cultural, with $F_{\text {hitung }}$ on educational aspirations is 11.022 and significance level of 0.001 . Aspiration office get results $F_{\text {hitung }}$ equal to 18.510 and the significance level of 0.000. In accordance with hypothesis testing criteria, if $\operatorname{Sig}<0.05$, it means that there are significant differences between educational and occupational aspirations male and female students Batak Karo cultural.

\section{Differences in Education and Occupational Aspirations Students Men and Women Melayu Deli Cultural}

Results showed that there was no difference in the educational aspirations of male and female students Melayu Deli cultural backgrounds, with $F_{\text {hitung }}$ equal to 7.023 and a significance level of 0.009. In accordance with hypothesis testing criteria, if $\operatorname{Sig}<0.05$, it means that there are significant differences between educational aspirations male and female students Melayu Deli cultural.

As for the occupational aspirations of men and women Melayu Deli, obtained $\mathrm{F}_{\text {hitung }}$ equal to 0.954 and a significance level of 0.330. In accordance with hypothesis testing criteria, if Sig>0.05, meaning that there are no significant differences between the aspirations of office male and female students Melayu Deli cultural.

\section{Difference Educational and Occupational Aspirations Students Batak Karo and Melayu Deli Cultural}

Findings show that there is no significant difference between educational and occupational aspirations of high school students Batak Karo and Melayu Deli, and the description of the data of high school students Batak Karo and Deli Malay same -Same at the high category. In accordance with the results of Hadjikyriakou (2009) who found that there were no significant differences between the educational aspirations and positions of American students and international students, but American 
students were significantly more confident achieve their educational goals rather than international students.

Besides, Suslu (2014), which compares students' educational aspirations of Turkey and the United States found that there was no significant difference between the Turkish and American students. Educational aspirations and positions students alike are at a very high level. The absence of differences in educational aspirations and office significantly in both cultures, indicating that the two cultures together form a student to be someone who has high aspirations to achieve success.

Borualongo (2014) explains that the students Batak group who received the highest score is the power and achievement. Culturally, Batak ethnic students are required to have more power and achievement,claims to have achievements to be proud of. In order to support the success of achievement, it is important to value-oriented self-direction,so that the student can direct himself in thinking of new ideas are creative. This indicated that the Batak people will have aspirations of education and a good job.

Melayu Deli traditional teachings in every individual should have ideals, both the ideals and the ideals of the world hereafter. Melayu Deli culture set the correct direction of ideals, which do continuities and cultural change with the times (Takari, Zaida \& Dja'far, 2014). Besides, Basyarsyah \& Syaifuddin (2002) describe the Melayu Deli prioritize education. This is reflected in the saying:"studying dont shy, true science that do not". In the basic values of Melayu Deli are one of the basic values of the values of ideals.

These values are inculcated from childhood to adulthood by Melayu Deli, the meaning of the phrase indicates, for the Melayu Deli community study was the thing to do, both men and women have equal studying without any distinction because of Melayu Deli society knowledge is a society that has dignity and a good dignity.

The results showed that there is no difference between educational and occupational aspirations of high school students Batak Karo and Melayu Deli because students are at the high school level has been able to identify and set goals to be achieved. It is also caused by the condition of acculturation. Students who live in Sibolangit and Galang has experienced acculturation, in which students are already experiencing a social process arising from their respective cultures are confronted with elements of a new culture, and new cultures are accepted into the culture without causing loss of cultural elements from students own.

Nirwana (2003) explains that the changes in cultural values that occur at this time will continue in the future, the cultural values that change is the result of man's work and will certainly affect the man himself. Therefore, the shift in cultural values that occur in students Batak Karo and Melayu Deli influence the way students identify the skills to be able to achieve the education and position desired in the future, allowing no different educational and occupational aspirations the students cultural backgrounds Batak Karo and Melayu Deli.

\section{Differences Educational and Occupational Aspirations Students Male and Female Batak Karo Cultural}

Findings show that there is a significant difference in educational and occupational aspirations male and female students Batak Karo. Ohlendorf \& Raferty study (1982) found male and female students have different educational aspirations and positions, young women have higher aspirations 
than boys. McNerney research results, Kristine, Coleman \& Christy (1998) found a significant difference between educational aspirations and positions of high school students based on gender. Women have higher aspirations than men.

The study's findings related to the theory of gender equality. Mansour (1997: 8) explains that the concept of gender is an inherent character of the men and women who are socially and culturally constructed. Besides, Culture Indonesian people in general is no longer distinguish between women and men in taking education. Of course this led to the emergence of consciousness that are culturally, women can achieve the same high level as men.

In Batak Karo men and women have differences in terms of position in the family. Batak cultural, men are the future generation descendant of his father, while women do not. This is because women are considered only temporary, that at some point after she married she would follow him and get into the clan of her husband (Torop, 2005). The magnitude of the man's responsibility enables it had educational aspirations and positions better. But Batak Karo women students have educational aspirations and a higher position than the male students Batak Karo, this is possible because the woman who pinned make him get up and have a high motivation to overcome inveriority experienced. In marriage, women Batak placed in an unfair position. If there is a divorce in the family of the wife / widow is not entitled to bring her husband's property. Given this, it is possible Batak educated woman became a strong woman because there are no guarantees for his life unless he himself who fought for it. This is thought to be the cause of high educational aspirations and positions Batak Karo women's student.

Besides, Nirwana (2003) explains that the tolerance and openness to the employment of women in the various sectors in the global community, particularly Indonesia seems to have affected the morale of the Batak women to be able to compete. This is one factor high educational aspirations and positions of female students Batak Karo. Changes the role of men and women in society, allegedly also a factor different educational aspirations and positions students and high educational aspirations and positions female students compared with male students Batak Karo. Even under the extreme patriarchal culture but change globally role also occurs in Batak Karo.

\section{Differences Education and Occupational Aspirations Students Men and Women Melayu Deli Cultural}

There are significant differences between students' educational aspirations Melayu Deli men and women. Melayu Deli female students more has high aspirations to education than male students Melayu Deli. As for the occupational aspirations of there is no difference between male and female students Melayu Deli.

Ohlendorf research and Raferty (1982) found that male and female students have differences in students' educational and occupational aspirations. Wilson and Wilson (in Mau and Bikos 2000) found that boys have higher aspirations than young women. Research McNerney, Kristine, Coleman \& Christy (1998) found that there are significant differences between educational aspirations and positions of high school students based on gender. Women have higher aspirations than men.

Results of research on these variables reject the results of previous studies. It also probably due to the influence of cultural factors. Where in the Deli Malay culture which uses bilateral kinship system, which is the mother and father have the same rights, as well as boys and girls. Van Errde (in Basyarsyah \& Syaifuddin, 2003) explains that characterize Deli Malay people are honest in trade, 
boldly sailed the seas, like working in the field of shipping, rarely involved in criminal matter and love to the rule of law.

The Melayu Deli in North Sumatra now have the lifestyle to pursue science as high, compete with other ethnic groups. In fact there are also studying abroad, because people really upholds Melayu Deli educational. They wanted a smart and intelligent, to be able to help everyone. In Melayu Deli is located on the bilateral system so that the concept of similarity men and women are on an equal footing causing student educational aspirations and positions of women and men are not too different.

\section{Conclusions}

Based on research findings and hypothesis testing as well studied and described in the discussion of the research, it can be summed up as follows: There is no significant difference between educational and occupational aspirations students' cultural backgrounds Batak Karo and Melayu Deli, and educational aspirations and occupational aspirations students Batak Karo and Melayu Deli at the high category.

There are significant differences between the educational and occupational aspirations male and female students' Batak Karo, Batak Karo women students have educational and occupational aspirations a higher than the male students Batak Karo. There are significant differences between the educational aspirations of male and female students Melayu Deli cultural backgrounds. Melayu Deli female students have higher educational aspirations than students Melayu Deli men, and there are no significant differences between the occupational aspirations of male and female students Melayu Deli.

\section{Acknowledgments}

I am enormously grateful to Prof. Dr. Muri Yusuf, M.Pd., and Prof. Dr. Herman Nirwana, M.Pd., Kons., for his continuous encouragement and advice my study. To my parents, my brother and sister for their unending support.

\section{References}

Basyarsyah, LS, \& Syaifuddin, W. (2002). East Sumatra Malay culture. Terrain: Usu Press.

Borualongo.(2014). "Study of Ethnic Student Value Systems in Batak, Minang, Javanese, and Sundanese in Bandung".Proceedings Social SnaPP2014, economics andhumanities.ISSN 20893590 । EISSN 2303-2472.4 (2): 99-106.

Gutman, LM, \& Akerman, R. (2008). Determinants of Aspirations. Research Report,(27): 1-30.

Husni, 1978. THM Civilization History Trails EastSumatra.Jakarta: Ministry of Education and Culture Publishing Textbook Project and Regional Indonesian Literature.

Mansour, F. 1997. Analysis of Gender and Social Transformation. Yogyakarta: Student Reader Offset.

Mau, WC (1995). Educational Planning and Academic Achievement of Middle School Students: A racial and cultural comparison. Journal of Counseling \& Development, 73, 518-526.

Mau, WC, \& Bikos, L. H. (2000). "Educational and Vocational Aspirations of Minority and Female Student". Journal of Counseling \& Development, 1 (78): 186-193.

McClelland, I. (2013). Research Into Education Aspiration for regional Victoria. Research Report. Regional Policy Advisory Committee.

McNerney, KA, \& Coleman, C.L. (1998). Educational and Occupational Aspiration of High School Students. Educational Research Association, 143: 3-15.

Nirwana, H. (2003). Relationship Level Aspirations and Perceptions of Learning with Math Learning Outcomes of the General Secondary School Students Set Rear Minangkabau and Batak culture. dissertation. Unpublished Malang: UNM Graduate Program. 
Ohlendorlf, GW, \& Ratlerty, D. M. (1982). The Educational and Occupational Aspirations of Louisiana Rural High School Students: A comparative study. Eric, 737: 3-23.

Prints, D. 2014. IndigenousKaro.Terrain: Bina Media Pioneers.

Quaglia, RJ, \& Cobb, C.D. (1996). Toward a Theory of Student Aspirations. Journal of Research in Rural Education, 12 (03): 127-132.

Suslu, D., A. (2014). Educatial Aspirations of Middle and High School Students: A Focus on TurkishAmerican Youth. A Dissertation. Istanbul: BA, Istanbul University.

Takari, M., Zaida, B., \& Dja'far. (2014). Malay Customary Marriages. Terrain: Usu Press.

Torop, E.S. (2005). Kids notch Perempuaan In Inheritance Law Indigenous Peoples Batak Toba In the City District of Pontianak in Pontianak. thesis. Unpublished Semarang: Diponegoro University.

Yusuf, A.M. (2002). How to succeed in acareer. Padang: Ghalia Indonesia.

Yusuf, A. M. (2014). Methods: Quantitative, Qualitative, and the Joint. Research. Jakarta: Prenadamedia Group. 